\title{
Role of Andaman and Nicobar Islands in the Indo-Pacific: India's Eastern Anchor
}

\author{
Muraliprasath $\mathrm{P}^{1}$
}

\begin{abstract}
The Indo-Pacific becomes the geopolitically contested zone in the twenty first century. The Indian Ocean that had remained quiet after the cold war is emerging as a critical hotspot for geostrategic competition in the Indo-Pacific. In History, Islands played a vital role in shaping the maritime interest of the nations. The Andaman and Nicobar Islands have rich maritime history right from the Chola dynasty to the Second World War. The strategic location of the Andaman and Nicobar Islands offers India an opportunity to alter its maritime dynamics in the eastern Indo-Pacific. These islands are critically situated near the western entrance of the Strait of Malacca, Indonesia and Myanmar. The Andaman Sea is the key to busiest SLOCs, especially the shipping route that passes through just south of the Nicobar Islands into the Strait of Malacca. Further in view of India-China maritime competition in the IOR, these Islands gain strategic significance.
\end{abstract}

In the Post-Cold War era, India lacked in the appreciation of the importance of these Islands in terms of Development, Connectivity, Commerce and Security. Indian Prime Minister Modi's recent doctrine and policies towards these islands will come to play a dominant role in shaping the new order in the eastern Indo-Pacific region. These formerly neglected Islands have now become one of the emerging hotspots as they are proving to be vital to India's aspiration of being a 'net security provider' in the region.

This paper attempts to analyze the emerging significance of Andaman and Nicobar Islands for India in the context of the Indo-Pacific and enumerates its strategic advantages.

Keywords: Indo-Pacific region, The Andaman and Nicobar Islands, Sea lanes of Commerce, MILAN, SIMBEX, Andaman and Nicobar Tri-Service Command, Indian Ocean region.

\footnotetext{
${ }^{1}$ Muraliprasath is a Research Candidate at UGC Centre for Maritime Studies, Pondicherry University, Puducherry, India. This paper was presented by the author during the webinar on Emerging India from Maritime Perspective to commemorate National Maritime Day on 05 April 2021. The Event was co-hosted by EJSSS along with UGC Centre for Maritime Studies, Pondicherry University
} 


\section{What is the Indo-Pacific?}

The term "Indo-Pacific" is first used by Dr.Gurpeet S. Khurana (Khurana, 2007) who was the executive director of the National Maritime Foundation (NMF), New Delhi. Khurana, a captain in the Indian Navy has been credited with the first use of this term in strategic and geopolitical discourse in India. The Indo-Pacific regards the singular geopolitical construct, where lie tremendous geo-economics opportunities and security challenges for Asia and the rest of the world (Kuo, Jan 25, 2018). Indo-Pacific has recently witnessed its place in white papers of four of the world's largest democracies: Australia, Japan, India, and the United States, better collectively known as "QUAD." This illustrates the importance of the region in foreign policy pronouncements of these four countries in particular and for Asia in general. The white papers of all these countries repeatedly mentioned Indo-Pacific and stressed the need to proactively secure this region for the peace, growth, and stability of Asia. Japan is the first nation to initiate the use of the term IndoPacific in its official documents. In April 2017, Japan's Ministry of Foreign Affairs released its white paper. It promoted a "Free and Open Indo-Pacific Strategy" as a part of its foreign policy aimed at proactively "securing the peace, stability, and prosperity of the international community". The Japanese construct of the Indo-Pacific is based on combining the two giant oceans and the two continents of Asia and Africa. Developing interconnectivity and infrastructure projects among the developing economies of these two large landmasses seem to form the heart of the Japanese concept of a Free and Open Indo-Pacific (FOIP). Australia's maritime-based economy requires unfettered access to trading routes, secure communications, and transport to support its economic development in the long run. The Australian construct is to a "stable and prosperous" Indo-Pacific region. The US strategic shift toward the Indo-Pacific region could be determined because the US Pacific Command (USPACOM) was renamed US Indo-Pacific Command (US INDOPACOM) in May 2018. Even Though the term "Indo" in the Indo-Pacific represents the Indian Ocean, not India, the global communities expect India to play a significant role in ensuring an environment conducive to economic growth and development.

\section{India's Approach in the Indo-Pacific}

India's geopolitical location, capability and ambitions, and the various threat perceptions present in the Indo-Pacific will remain critical determinants in shaping its position in the region. India also possesses one of the fastest-growing economies in the world. Growing economic ambitions come 
with more responsibilities and an appetite to play a more prominent role in the regional geopolitics and security architecture. India, too, is looking forward to its role as a "net security provider" in the Indo-Pacific. In the post-cold war era, India extends its relations with Southeast Asian nations with the Look East policy's inauguration. With one step forward, Prime Minister Modi subsequently changed it as ACT EAST policy. In 2018, Shangri La dialogue in Singapore, Narendra Modi called for a free, open, and inclusive Indo-Pacific region, resting on territorial integrity and sovereignty of all nations and settlement of disputes based on International Law. PM Modi has launched Indo-Pacific Oceans Initiatives at the East Asia summit in 2019 to focus on maritime security issues, disaster reduction, trade connectivity, and maritime transport. (Chaudhury, Nov 05, 2019). India was also working with the Bay of Bengal Initiative for Multisectoral Technical and Economic Cooperation (BIMSTEC) for regional integration. The BIMSTEC was energized with the BRICS-BIMSTEC outreach summit in 2016 to promote multimodal physical connectivity in the Bay of Bengal region. (The Hindu, Oct 15, 2016). Modi explicated his vision of SAGAR, making the Indian Ocean region his foremost policy priority. The policy is conceptually based upon actively pursuing and promoting India's geopolitical, strategic, and economic interests on the seas, in particular the Indian Ocean. India has also been working with IORA - Indian Ocean Rim Association - since 1997 to secure eight maritime-based focused areas. Over the past few years, India's foreign policy approach focused on immediate bilateral and multilateral importance. India and the United States have signed agreements for allowing greater bilateral interoperability and technology transfer, involving the Logistics Exchange Memorandum of Association (LEMOA). Other than the US, The Indian Navy regularly carries out naval exercises to increase interoperability in the maritime domain with several countries such as Singapore (SIMBEX), France (VARUNA), Australia (AUSINDEX), Oman (Sea Breeze), Japan (JIMEX), and Myanmar (MILAN and CORPAT). The scope of these exercises has remained limited to the Bay of Bengal and the Andaman Sea.

\section{Background and Strategic significance of Andaman and Nicobar Islands}

\section{Historical Importance}

The Andaman and Nicobar Islands have a colorful maritime history from the ancient period to the colonial period. People discourse not much aware about when and how the first inhabitants came 
to the island. Based on the earliest archaeological shreds of evidence goes back 2,200 years, i.e., Old Stone Age. In that period, the ANI peoples may have diversified into many groups, now called tribes. Rajendra Chola, one of the efficient kings in the Chola dynasty, used these islands as its navy base against the Sriwijaya Empire at present Indonesia. Denmark is the first colonial power to conquest these islands via its Asiatic company. They remained nominally till the British took over control in 1851. Japanese invaded these islands from British during Second World War from 1942 to 45 (Tamta, 1992). Many ports, roads, and connectivity infrastructure were developed in these three and half years of the Japanese period. Japan was the first to realize the potential of these islands from both maritime and aviation aspects. British reoccupied these islands from Japan in October 1945, under the statesmanship of Bishop Richardson (Kaul 2014). In the PostIndependence India, Bishop Richardson became the leader of the Nicobarese group. These Islands formed a part of the Indian Union in 1947. Today Andaman and Nicobar are among the nine union territories of India.

\section{Strategic significance}

ANI occupies only $0.2 \%$ of India's landmass. Simultaneously, these islands cover $30 \%$ of India's EEZ (Exclusive Economic Zone). Port Blair, the capital of these islands, is just 20 nautical miles away from Myanmar, and the southern point is known as Indra point, is just 90 nautical miles away from Indonesia. (Kaul 2014) The archipelago comprises 572 islands, of which only 37 islands are inhabited. The Andaman group of islands covers an area of 6408 sq km having 325 islands, and the Nicobar group has an area of $1841 \mathrm{sq} \mathrm{km}$ with 24 islands. The long chain of Andaman and Nicobar Islands located at the mouth Strait of Malacca's entrance, and straddling this one of the most crucial trade chokepoints of the world, form a valuable strategic asset. For India, these islands can play a pivotal role in the developing 21 st-century maritime competition between India and China. The Strait of Malacca runs between Indonesia, Malaysia, and Singapore, connecting the Andaman Sea of the Indian Ocean and the South China Sea. As the connection between the Indian Ocean and the South China Sea, the Strait of Malacca is the littlest sea route between India and China and hence is one of the most massively traveled shipping channels in the world (Roy, 2017) The Malacca Strait has served as the main transit route supplying vital commodities to fuel the fast-growing economies of Asia and beyond. As much as 75\% of China's oil imports from the Gulf region pass through these SLOCs, and it makes it the main artery for China's energy lifeline. Alternate routes close to Malacca Strait, such as the Straits of Lombok and Makassar, are longer 
and take about five additional days. The Chinese presence in and around the Malacca Strait in the Andaman Sea, Bay of Bengal, and the Arabian Sea should be a cause of concern for the Indian decision-makers. Some of China's significant moves threaten Indian interest, especially in and around the Andaman and Nicobar Islands. China has been funding and executing new ports modernizing existing ports in many countries along the IOR from a part of its Maritime Silk Road initiative. Trilateral Highway Project in Myanmar, Hambantota port at Sri Lanka under ninetynine years of a lease under China, is the classic example of China's Debt Trap Diplomacy. The present Indian government has awakened to the likelihood of a profound Chinese engagement in the Indian Ocean. Prime Minister Modi has taken the initiative and is paying a considerable amount of attention to the overall maritime security of India and with the Development of ANI by Act East Policy in particular. By Utilizing Act East Policy, India needs to focus on the holistic development of these islands through a combination of strategic investments and increasing military strength in the Andaman and Nicobar Islands to counter China.

\section{Importance of the Andaman and Nicobar Command (ANC)}

Post the Kargil Conflict in 1999, on the Kargil review committee's recommendations, the Group of Ministers approved the establishment of an integrated Command in May 2001. Thus ANC, the first and the only Unified Operational Command was raised in October 2001. The ultimate aim of establishing this command is to foster jointmanship among the three services, such as Army, Navy, Air force, and coast guard in Andaman and Nicobar Islands' unique operational environment. The Role of ANC is all about encompassing "Defense of Andaman and Nicobar Islands' "including its waters, airspace, Humanitarian Assistance, and Disaster relief and protection of future offshore installation when they come up (Roy \& cawasji, 2017). ANC continuously involves in Defense Diplomacy through various joint naval exercises with its maritime neighbors. Such as CORPAT, MILAN, SIMBEX in the Andaman Sea. ANC also patrols to suppress gun running, narcotics smuggling, piracy and poaching and conducts maritime surveillance. The INS KOHASSA airfield located at the northernmost part of these islands holds strategic significance. With the inclusion of this airfield, The Andaman and Nicobar Command's (ANC) capability to operate freely from all the regions of the Andaman and Nicobar Islands with a significant breakthrough, as per Headquarters Andaman Nicobar Command ANC to Enhance Its Operational Capability with the Upcoming Commissioning of INS Kohassa, (PIB, 2019). The INS KOHASSA and other airfields 
in the ANC will fulfill India's role as a net security provider in the region and enhance the capability of ANC to carry out non-traditional security cooperation (Kumar, Mar 15, 2019).

\section{Andaman and Nicobar Islands in the context of Indo-Pacific}

\section{Counterbalancing the Chinese influence}

Andaman and Nicobar Islands can further India's political, economic, and military interest in the Indo-Pacific region, especially in the face of growing influence and presence of the Chinese. An increase of Chinese influence in the littoral states using the "string of pearls" strategy can be counterbalanced by India's push towards the development of Andaman and Nicobar islands using the 'SAGAR MALA' initiative and Act East Policy (Dixit, 2019).

\section{Geopolitical asset}

A combination of Geographical location by straddling the choke point of Malacca strait, at a distance of $1200 \mathrm{~km}$ from Indian Mainland and north-to-south spread of these islands stretching over $750 \mathrm{~km}$ makes ANI a valuable geopolitical asset in the 21 st century by playing a crucial role in maritime competition in the Indo-Pacific.

\section{Surveillance and Power Projection}

ANI facilitates domination of the Bay of Bengal, the Six-degree channel, and the ten-degree channel, also parts of the Indian Ocean. These islands could provide multiple military operations for India to keep the busiest sea lanes under surveillance and for power projection. India aims to launch joint projects with Japan and the United States to fix sound surveillance sensors (SOSUS) in the proximity of these islands. It will enhance India's underwater maritime domain awareness in this region, like the existing US-Japan "Fish Hook" SOSUS network in the South China Sea and the Indian Ocean Rim. This is a significant part of controlling, monitoring the Chinese influence, and tracking the movements of Chinese submarines in the deep Indo-Pacific region.

\section{Conclusion}

To sum up, if India is to bolster its presence in the Indian Ocean and Indo-Pacific, it must take advantage of its geography, specifically the Andaman and Nicobar Islands. These Islands can be built up as a self-sustaining economic Model and rationale for developing commercial and military infrastructure as a "dual maritime eco-system". Recently India has initiated the Chennai-Andaman Optic fiber cable laying project which is a positive step to promote development of these islands 
(The Hindu, Aug 10 2020) (Chowdhury, Aug 11, 2020). These formerly abandoned islands have now become one of the emerging hotspots for India. It allows India long-time aspiration of being a "net security provider" in the wider Indo-Pacific region.

\section{References}

Khurana, G.S. (2007). Security of Sea Lines: Prospects for India-Japan Cooperation. Strategic Analysis, 31(1), Pp 139-153

Kuo, Mercy A. (January 25, 2018). The Origin of 'Indo-Pacific' as Geopolitical Construct Insights from Gurpreet Khurana, THE DIPLOMAT. Retrieved from: https://thediplomat.com/2018/01/the-origin-of-indo-pacific-as-geopolitical-construct/

Brown, James D. J. (April 3, 2018). Japan's Indo-Pacific Strategy Falls Short, Japan Times, April 3, 2018. Retrieved from: https://www.japantimes.co.jp/opinion/2018/04/03/commentary/japancommentary/japans-indo-pacific-strategy-falls-short/ accessed April 25, 2018.

Department of Foreign Affairs and Trade, Commonwealth of Australia, 2017 Foreign Policy White Paper, 2017, 3. Retrieved from: https://www.fpwhitepaper.gov.au.accessed April 25, 2018,

Bhatt, Pooja (February 4, 2018). America First and Its Implications for the Indo-Pacific, South Asian Voices. Retrieved from: https://southasianvoices.org/america-first-and-its-implicationsfor-the-indo-pacific/ accessed April 27, 2018.

Ministry of External Affairs, Government of India (December 23, 2015). Act East Policy. Retrieved from: http://pib.nic.in/newsite/PrintRelease.aspx?relid=133837 accessed April 25, 2018.

Raja Mohan, C. (November 13, 2018). Raja Mandala: New ripples in the Andaman Sea, Indian Express. Retrieved from: https://indianexpress.com/article/opinion/columns/narendra-modisingapore-visit-look-east-policy-shangri-la-dialogue-andaman-sea-5443200/, Accessed on February 16, 2019.

The full text of the speech made by Prime Minister Modi is available at http://www.mea.gov.in/SpeechesStatements.htm?dtl/29943/Prime+Ministers+Keynote+Address + at+Shangri+La+Dialogue+June+01+2018

Chaudhury, Dipanjan Roy (Nov 05, 2019). PM Modi proposes Indo-Pacific Oceans Initiative Economic Times. Retrieved from: https://economictimes.indiatimes.com/news/politics-andnation/pm-modi-proposes-indo-pacific-oceans- 
initiative/articleshow/71915838.cms?utm_source=contentofinterest\&utm_medium=text\&utm_ca mpaign=cppst \& https://economictimes.indiatimes.com/etreporter/author-dipanjan-roychaudhury-479233067.cms

The Hindu (October 15, 2016). Goa BRICS Summit to see Outreach to 7-nation BIMSTEC, The Hindu. Retrieved from: https://www.thehindu.com/news/national/Goa-BRICS-Summit-to-seeoutreach-to-7-nation-BIMSTEC/article16072083.ece

Udhas, Pradeep (Jul 31, 2018). Creating a US-India Security Advantage in the Indo-Pacific | Forbes India Blog. Retrieved from: https://www.forbesindia.com/blog/economy-policy/creatinga-us-india-security-advantage-in-the-indo-pacific/

Tamta, B.R. (1992). Andaman \& Nicobar Islands, National Book Trust, New Delhi.

Rev. Canon John Richardson, Car Nicobar under Japanese Occupation: 1943 to 1945, June 1947 unpublished, p. 4.

Kaul, Sanat (2014). Andaman and Nicobar Islands: India's Untapped Strategic Assets, Pentagon Press: New Delhi.

Roy, P. K. and Cawasji, Aspi (2017). Strategic vision-2030: security and development of Andaman \& Nicobar Islands, Vij Books: New Delhi.

Global Security (n.d.). Andaman and Nicobar Command. Retrieved from: http://www.globalsecurity.org/military/world/india/anc.htm

Giles, Denis (October 07, 2015). Andaman and Nicobar Command to Celebrate its 15th Raising Day, The Andaman Chronicle. Retrieved from: http://www.andamanchronicle.net/index.php? option=com_content \&view=article \&id=7517:andaman-and Nicobar-command-to-celebrate-its15th-raisingday $\&$ catid $=37 \&$ Itemid $=142$

PIB (Jan 18, 2019). Headquarters Andaman Nicobar Command ANC to enhance its operational capability with the upcoming commissioning of INS Kohassa. Retrieved from: https://pib.gov.in/Pressreleaseshare.aspx?PRID=1560445

Kumar, Dr. Amit (March 15, 2019). Andaman \& Nicobar Islands: Policy of Masterly Inactivity and Benign Neglect to Proactive Development, Indian Council of World Affairs. Retrieved from: https://www.icwa.in/show_content.php?lang=1\&level=3\&ls_id=4309\&lid=3200\#: :text=Viewp oints-

Andaman $\% 20 \% 26 \% 20$ Nicobar $\% 20$ Islands $\% 3 \mathrm{~A} \% 20$ Policy $\% 20$ of $\% 20$ Masterly $\% 20$ Inactivity $\% 2$ 0and,Benign $\% 20$ Neglect $\% 20$ to\%20Proactive\%20Development\&text=By\%20leveraging\%20the $\% 20$ potential\%20of,India's\%20defence\%20and\%20security\%20strategy.

Giles, Denis (Aug 07, 2017). Andaman's Gearing Up for The 10,000 Crore Sagarmala Project. Retrieved from: 
http://andamanchronicle.net/index.php?option=com_content\&view=article\&id=11702:andamans -gearing-up-for-the-10-000-crore-sagarmala-project\&catid=37\&Itemid=142. Accessed: $2021-04-$ 13

Dixit, R. (2019). Modi's 2.0 foreign policy to lay stress on 'SAGAR Doctrine' and 'Act East,' Retrieved September 8, 2020, from https://www.theweek.in/news/india/2019/06/06/modiforeignpolicy-lay-stress-sagar-doctrine-and-act-east.html

Singh, Abijith (June 15, 2016). India's "UNDERSEA WALL" in the Eastern Indian Ocean, CSIS. Retrieved from: https://amti.csis.org/indias-undersea-wall-eastern-indian-ocean/

The Hindu (Aug 10, 2020). PM Modi launches submarine optical fiber cable to Andaman \& Nicobar Islands, The Hindu. Retrieved from: https://www.thehindu.com/news/national/pmlaunches-submarine-optical-fibre-cable-to-andaman-nicobar-islands/article32314430.ece Accessed on August 11, 2020.

Chowdhury, Diparanjan Roy (Aug 11, 2020). Cable linking Andaman's strengthens India's strategic Outreach to Indo-Pacific, The Economic Times. Retrieved from: https://economictimes.indiatimes.com/news/defence/et-analysis-cable-linking-andamansstrengthens-indias-strategic-outreach-to-indo-pacific/articleshow $/ 77475309 . \mathrm{cms}$ ?from=mdr. Accessed August 11, 2020. 